\title{
POTRET KEPIMPINAN WANITA DALAM WAJAH SEORANG WANITA DARI PERSPEKTIF PENDEKATAN PENGURUSAN
}

\section{(Portrayal of Women's Leadership in Wajah Seorang Wanita from the Management Approach Perspective)}

\author{
Sara Beden \\ sara.beden@ipgmktar.edu.my \\ Jabatan Pengajian Melayu \\ Institut Pendidikan Guru Kampus Tun Abdul Razak
}

Published online: 1 December 2020

To Cite: Sara Beden. (2020). Potret Kepimpinan Wanita dalam Wajah Seorang Wanita dari Perspektif Pendekatan Pengurusan. Malay Literature, 33(2), 265-294.

\begin{abstract}
Wanita memiliki banyak keistimewaan dan berperanan penting dalam institusi keluarga. Dewasa ini ramai wanita yang menceburkan diri dalam pelbagai bidang pekerjaan termasuklah keusahawanan, perniagaan, dan politik. Artikel ini bertujuan untuk menganalisis ciri-ciri kepimpinan seorang wanita sebagai peneraju dan pentadbir keluarga yang biasanya diterajui oleh kaum lelaki. Kajian ini mengaplikasikan Pendekatan Pengurusan dengan penumpuan terhadap prinsip kepimpinan dengan menggunakan novel Wajah Seorang Wanita karya S. Othman Kelantan. Metode kepustakaan dan kualitatif diterapkan dalam kajian ini. Dapatan analisis memperlihatkan pengaplikasian tiga daripada empat dimensi dalam prinsip kepimpinan, iaitu dimensi pentadbiran, dimensi ekonomi dan dimensi pendidikan menerusi watak utamanya, Siti Musalmah. Siti Musalmah dipotretkan sebagai wanita yang berjaya memimpin dan mentadbir keluarganya setelah kematian suami tercinta. Kajian ini juga menzahirkan peranan wanita, sekali gus mengangkat martabat wanita sebagai ketua keluarga, meskipun watak utamanya terpaksa mengharungi cabaran yang hebat sebagai ibu tunggal. Impaknya, Pendekatan Pengurusan menerusi prinsip kepimpinan memiliki kekuatan untuk memugar dan merincikan ciri-ciri pengurusan yang dipraktikkan oleh
\end{abstract}

Abstrak 
kaum wanita bagi mensejahterakan keluarga sekali gus memotretkan kepimpinan wanita semasa zaman pendudukan Jepun.

Kata kunci: ciri-ciri, potret, dimensi pendidikan, dimensi pentadbiran, dimensi ekonomi

\begin{abstract}
Women have many advantages and important roles in the family institution. Nowadays, many women are involved in various professions including entrepreneurship, corporate positions and leadership. Therefore, this article aims to analyse the fundamentals of women's leadership as the head and manager of the family - roles traditionally reserved for men. This study applies the principles of leadership in the Management Approach on S. Othman Kelantan's novel, Wajah Seorang Wanita. Library research and qualitative methods were applied in this study. The analysis shows that three out of the four dimensions of leadership principles apply, namely, the administrative, economic and educational dimensions. This is depicted through the novel's main character, Siti Musalmah, who has to manage and lead her family after the death of her beloved husband. This study also seeks to unveil the role of women and thus elevate the status of women as heads of families despite having to face great challenges as single mothers. As a result, the Management Approach, using principles of leadership, allows a clarification and analysis of the principles of management practiced by women in caring for the well-being of their familis. Wajah Seorang Wanita is a portrayal of the leadership of a woman during the time of the Japanese Occupation.
\end{abstract}

Keywords: characteristics, portrayal, educational dimensions, administrative dimensions, economic dimensions

\title{
PENGENALAN
}

Tenas Effendy (2010, p.168) menegaskan bahawa "Pemimpin yang sejati akan memayungi dan menaungi rakyatnya ibarat "kayu besar di tengah padang, rimbun daunnya tempat berteduh, kuat dahannya tempat bergantung, kukuh batangnya tempat bersandar dan besar akarnya tempat bersila." Ungkapan berirama tersebut amat puitis yang mencerminkan keperibadian dan tanggungjawab serta amanah seorang pemimpin sejati. Pemimpin dipilih untuk memimpin dengan gaya kepimpinan yang berupaya memberikan kemakmuran dan kesejahteraan kepada rakyat yang dinaunginya. Walau 
bagaimanapun, pemimpin bukan sahaja terdiri daripada golongan kaum Adam, golongan Hawa juga memperlihatkan kehebatannya. Kehebatan wanita memimpin sudah terlakar dalam sejarah dunia apabila golongan wanita menunjukkan kehebatan dengan gaya kepimpinan yang relevan ketika menerajui kerajaan masing-masing sehingga disegani dunia. Mereka bukan sahaja ibu dalam sebuah keluarga malah "ibu" kepada seluruh rakyat dan pemimpin bagi kerajaan yang ditadbirnya.

Muhammad Rahimi dan Bahiyah (2017), membuktikan kewibawaan pemimpin wanita Melayu, iaitu Tun Fatimah Hashim sebagai Ketua Kaum Ibu United Malays National Organization (UMNO) yang bermula pada tahun 1956 hingga 1972. Sifat dan semangat Tun Fatimah Hashim sangat kental dan utuh semasa menjadi pemimpin dalam pertubuhan UMNO pada ketika itu. Pelbagai cabaran dan halangan yang ditempuhi sepanjang menjadi pemimpin dengan kewujudan patriarki yang masih tebal dan ketiadaan kerangka undang-undang yang bersifat membela dan memperkasa hak golongan wanita.

Annisa (2015, p.11) pula menegaskan bahawa pada hari ini, wanita tidak lagi dianggap lemah dan sentiasa berada di barisan belakang, tetapi mereka berupaya menempatkan diri di barisan hadapan sebagai pemimpin yang berjaya dalam pelbagai sektor yang kebanyakannya telah dimonopoli oleh lelaki. Wanita juga tidak lagi "terpasung"1 dalam pelbagai bidang, namun memperlihatkan kebangkitan yang drastik dan memainkan pelbagai peranan. Penegasan ini membuktikan bahawa kaum wanita di seluruh dunia sudah mentransformasi diri dan membuat anjakan paradigma dengan melibatkan diri dalam pelbagai bidang, hatta politik. Stigma bahawa wanita hanya layak berada di dapur ialah mitos yang semakin sirna. Adawiyah dan Salasiah Hanin (2012, p.7) menegaskan bahawa walaupun wanita dicipta dengan sifat kelembutan, dan kekuatan fizikalnya tidak setanding lelaki, namun wanita berhak melibatkan diri dalam bidang pekerjaan yang bersesuaian mengikut syariat Islam dan tidak bertentangan dengan fitrah kejadiannya.

Berdasarkan sorotan catatan lepas, didapati peranan wanita sudah terakam sejak zaman silam seperti yang dikisahkan dalam Sejarah Melayu (Shellabear, 1989). Sejarah Melayu turut merakamkan peranan signifikan kaum wanita menerusi watak Tun Fatimah dan Tun Kudu. Kedua-dua wanita ini berperanan besar dari segi sumbangannya kepada kemakmuran kerajaan Melaka walaupun tidak melibatkan diri dalam pentadbiran secara langsung. Watak Tun Fatimah dalam Sejarah Melayu tidak ditonjolkan sebagai pejuang atau terlibat dalam pertempuran. Walau bagaimanapun, Shaharom Husain(1991) 
telah mengangkat watak ini dengan menghasilkan sebuah novel yang bertajuk Tun Fatimah atau Riwayat Perjuangan Ibu Melayu pada tahun 1948. Beliau berhasrat menjadikan politik sebagai alat untuk mempengaruhi masyarakat pada zaman itu melalui novel dengan mengambil watak daripada karya sejarah lama, terutamanya Sejarah Melayu untuk dijadikan panduan dan teladan. Ekoran itu, beliau memotretkan watak Tun Fatimah sebagai pejuang wanita yang membela tanah air. Dalam novel ini, beliau menunjukkan bahawa kegagalan Malayan Union bukan sahaja disebabkan faktor perjuangan kaum lelaki, tetapi turut disertai kaum Hawa. Bagi beliau, wanita turut sama-sama bertarung nyawa untuk mempertahankan tanah air, bukan sekadar menjadi bunga perhiasan bangsa dan negeri. Gagasan ini pernah diketengahkan oleh A. Samad Said (1985, p.108) dalam naskhah kreatifnya Daerah Zeni dengan mengungkapkan pemikiran untuk memartabatkan golongan wanita menerusi nasihat Lazri Meon kepada anaknya Zeni dan Zedi. "Jangan biar diri jadi dayang atau hamba. Jadilah wanita yang sedia berganding bahu, boleh ke dapur, boleh ke lumpur, boleh bertempur sebelum ke kubur". A. Samad Said menyampaikan aspirasi perjuangan kepada golongan wanita agar berjuang, menjadi pejuang, berketerampilan dan serba boleh dalam pelbagai bidang.

A. Samad Said (1985) memberikan "kuasa" kepada wanita dalam Daerah Zeni menerusi watak Zeni dan Zedi yang memiliki kebebasan berfikir dalam ruang kebebasan yang terarah dan rasional untuk mendapatkan kebahagiaan. S. Othman Kelantan (2005) dalam Wajah Seorang Wanita (selepas ini WSW) pula telah merakamkan perjuangan dan ketabahan seorang wanita Kelantan yang meneruskan kehidupan dalam kepayahan setelah kematian suaminya. Wanita yang dipotretkan oleh S. Othman Kelantan dalam novel WSW yang diterbitkan pada tahun 1990 dan diulang cetak kali kedua pada tahun 2005 merincikan perjuangan seorang pemimpin keluarga yang tabah dan kental walaupun setelah diduga dengan kematian demi kematian. Kematian yang bermula dengan anak-anaknya, diikuti ayah, suami dan ibunya.

Artikel ini bertujuan untuk menganalisis ciri-ciri kepimpinan wanita dalam novel WSW karya S. Othman Kelantan (2005) berdasarkan Pendekatan Pengurusan dengan penumpuan terhadap prinsip kepimpinan yang diketengahkan oleh Mohamad Mokhtar (2013).

\section{SOROTAN LITERATUR}

Sorotan literatur membincangkan kajian lepas berkaitan dengan wanita sebagai pemimpin serta usahawan. Kajian berkaitan dengan wanita sebagai usahawan diteliti oleh Siti Khariah (2012) yang bertajuk "Analisis Citra 
Usahawan Wanita dalam Novel-novel Melayu”. Kajian ini menggunakan pendekatan feminisme dan moral Islam untuk menganalisis watak wanita yang terlibat secara langsung dalam usaha membina empayar perniagaan dalam novel Melayu. Dapatan kajian ini menunjukkan bahawa Titik Hamidah menyahut seruan agama Islam yang menggalakkan wanita menceburkan diri dalam bidang perniagaan sehingga menjadi jutawan. Sementara watak Kak Yam, seorang lagi wanita korporat yang telah membina empayar perniagaan yang dikisahkan dalam novel Menuju Ke Puncak. Novel Ke Mana Kasih Hendak Dibawa karya Khadijah Hashim juga membawa citra wanita korporat yang berjiwa besar dan ingin membina empayar perniagaan menerusi watak Sarah dan Sakinah.

Annisa (2015) dalam kajiannya yang bertajuk "Gaya Kepemimpinan Perempuan", mendapati pemimpin dapat mempengaruhi orang bawahannya untuk melaksanakan tugas, seterusnya mencapai visi dan misi syarikat untuk menjadikan organisasi lebih maju dan bersatu. Beliau mendapati peranan wanita tidak hanya tertumpu pada proses pembangunan, tetapi sebagai asas yang berstruktur dalam pembinaan sosial. Nor Aziza et al. (2018) pula telah membuat penelitian tentang faktor yang mempengaruhi kejayaan usahawan wanita di daerah Kubang Pasu, Kedah. Hasil dapatan menunjukkan bahawa terdapat hubungan yang sederhana antara media sosial dengan sumber kewangan dalam kejayaan usahawan wanita di daerah Kubang Pasu, Kedah. Impak kajian Nor Aziza et al. (2008) ini memberikan sumbangan kepada penyelidik, pengamal teori dan pengurusan untuk mengukur keupayaan daya saing usahawan wanita dalam usaha mengharungi cabaran globalisasi.

Tasnim (2018) pula membuat penelitian yang bertajuk "Kepimpinan Wanita dari Kaca Mata Islam" yang memberikan fokus terhadap kebolehan dan keabsahan menggalas tugas pemimpin dan penyelenggara urusan politik dan sosial. Dapatan memperlihatkan bahawa pengalaman dan pemahaman mereka yang kritis berlandaskan tradisi Islam telah meletakkan kepimpinan wanita dalam konteks yang tepat dan praktikal serta sewajarnya sesuai dengan sifat, pembawaan, keperibadian dan kedudukan mereka sebagai pemimpin. Hal ini selaras dengan keupayaan, naluri dan fitrah kewanitaan yang sebenar. Rosnani \& Nik Rafidah (2018) membuat penelitian terhadap novel Nenek karya Razali Endun dengan menggunakan teori psikoanalisis Sigmund Freud. Hasil analisis mendapati bahawa terdapat beberapa karisma yang diterapkan dalam novel Nenek, antaranya termasuklah karisma sebagai pemimpin, karisma sebagai pencinta kebudayaan Melayu, karisma sebagai wanita intelektual dan karisma sebagai wanita bertanggungjawab. Impaknya, 
teori psikoanalisis berupaya membuktikan bahawa imej wanita dalam novel Nenek bersifat positif.

Sorotan literatur menggunakan novel $W S W$ diperlihatkan menerusi kajian Tuan Rusmawati dan Mawar (2018). Kajian ini mengaplikasikan kerangka Gagasan Profetik oleh Kuntowijoyo. Pertimbangan menerusi rumus profetik memperlihatkan kemandirian watak wanita mendepani isu ketidakadilan ekonomi dan ketidakadilan gender dalam kerjaya. Pertimbangan ini berdasarkan kaca mata Islam dengan berpandukan salah satu daripada rumus profetik, iaitu nahi mungkar. Kajian ini mendapati bahawa S. Othman Kelantan telah berjaya mengangkat isu keprofetikan, iaitu peranan wanita Islam dalam pembudayaan amalan dan nilai-nilai keislaman yang sekali gus meneguhkan tradisi Melayu-Islam. Tuan Rusmawati, Mawar dan Muammar Ghaddafi (2018) turut merungkaikan aspek etika tu'minubillah dalam novel ini yang merupakan salah satu etika Sastera Profetik dalam Gagasan Profetik oleh Kuntowijoyo. Dapatan memperlihatkan bahawa menerusi Gagasan Profetik, S. Othman Kelantan memperagakan ketekalannya, iaitu mengangkat watak-watak wanita dalam novel ini. Penganalisisan menggunakan etika tu'minubillah mendapati bahawa pemeragaan watak wanita berdasarkan Wajah Seorang Wanita menjadi puncak tertinggi yang menggambarkan ciri-ciri umat terbaik. Watak Siti Musalmah dikesani menepati etika tu'minubillah. Kajian ini mengimplikasikan bahawa S. Othman Kelantan menyerlahkan aspek latar diri pengarang yang merentas akar tradisi Melayu-Islamnya.

Rangkumannya, sorotan literatur berkaitan dengan wanita sebagai usahawan dan pemimpin sama ada dalam kajian kes mahupun menggunakan data novel, memperlihatkan perkembangan yang positif serta signifikan. Senario ini menunjukkan bahawa kajian tentang pelibatan wanita dalam pelbagai bidang memerlukan kajian lanjut bertitik tolak daripada peranan wanita yang semakin signifikan. Nik Safiah (1990, p.71) berpendapat bahawa pemimpin tidak lahir dengan bakat dan keupayaan untuk memimpin. Pemimpin perlu dibentuk, dipupuk dan dilengkapkan dengan kemahiran tertentu. Oleh itu, wanita berupaya untuk menempatkan diri mereka dalam pelbagai bidang jika mereka berusaha untuk mencapainya dengan mengambil peluang dan ruang yang terbuka luas. Kajian terdahulu memperlihatkan impak yang positif dari pelbagai dimensi dapat menjadi panduan, kayu ukur dan rujukan kepada para pengkaji untuk membuat penilaian terhadap penglibatan wanita dalam pelbagai bidang. Sementara sorotan kajian dengan menggunakan novel $W S W$ memberikan fokus kepada Gagasan Profetik dan tidak membincangkan aspek kepimpinan seorang wanita sebagai pentadbir keluarga. Kajian yang 
dilakukan ini memberikan fokus terhadap ciri-ciri kepimpinan watak seorang wanita khususnya wanita Islam dalam hal mengurus dan mentadbir keluarga berdasarkan dimensi dalam prinsip kepimpinan.

\section{PENDEKATAN PENGURUSAN}

Artikel ini mengaplikasikan pendekatan pengurusan yang diperkenalkan oleh Mohamad Mokhtar (2013) dalam kertas kerjanya yang bertajuk "Pendekatan Pengurusan: Satu Metode dalam Kritikan Sastera". ${ }^{2}$ Selanjutnya, beliau membuat perincian yang mendalam dan komprehensif terhadap pendekatan ini menerusi syarahan perdana yang dianjurkan oleh Akademi Pengajian Melayu, Universiti Malaya pada 4 Ogos 2016. Mohamad Mokhtar (2016) telah merincikan konsep, ciri-ciri dan setiap prinsip dalam pendekatan ini yang relevan untuk menganalisis sesebuah teks sastera sama ada genre sastera moden mahupun sastera tradisional. Pendekatan ini mengandungi lima prinsip, iaitu Prinsip Perancangan, Prinsip Kepimpinan, Prinsip Pengorganisasian, Prinsip Penstafan dan Prinsip Kawalan. Walau bagaimanapun, perbincangan dalam artikel ini dibataskan dengan menggunakan prinsip kepimpinan sebagai landasan analisis. Pendekatan ini telah digunakan oleh Mohamad Zuber, Sara dan Mohamad Mokhtar (2014) ${ }^{3}$ menerusi kajian yang memberikan fokus terhadap dimensi pendidikan dalam Hikayat Awang Sulung Merah Muda selain kajian Sara (2018) ${ }^{4}$ yang memberikan fokus terhadap prinsip perancangan.

$\operatorname{Sara}^{5}(2019$, p.47) berpendapat bahawa prinsip kepimpinan dalam Pendekatan Pengurusan dapat memperlihatkan kecenderungan ciri-ciri kepimpinan yang sistematik dan berkarisma. Kamus Dewan Edisi Keempat (2019, p.1208) mendefinisikan pemimpin sebagai orang yang memimpin manakala kepimpinan pula ditakrifkan sebagai keupayaan memimpin. Cartwright dan Zander (1960, p.50) menegaskan bahawa kepimpinan ialah tingkah laku yang mempunyai keupayaan mengubah haluan sesuatu organisasi. Northouse (2007, p. 3) pula mentakrifkan kepimpinan sebagai, “A process whereby an individual influences a group of individuals to achieve a common goal'. Northouse (2007, pp. 4-5) membahagikan kepimpinan kepada dua bentuk, iaitu kepimpinan tret dan kepimpinan proses. Kepimpinan tret merujuk kalimat "she is a natural leader" dan "born to be a leader". Kepimpinan tret menyifatkan seseorang memiliki keistimewaan atau perwatakan atau kualiti yang melayakkannya menjadi pemimpin atau dilahirkan sebagai pemimpin. Sementara kepimpinan proses menekankan interaksi antara 
pemimpin dengan pengikut yang bakat dan kemahiran kepimpinannya diasah menerusi pendidikan dan proses sosialisasi. Mohamad Mokhtar (2016, p. 11) mentakrifkan kepimpinan sebagai seni atau proses mengetuai dan mempengaruhi kegiatan manusia yang berkaitan dengan tugas mereka supaya mereka giat untuk mencapai matlamat organisasi. Sementara Azman (2012, p. 125) mentakrifkan kepimpinan ialah suatu proses menggerakkan manusia dan organisasi yang dipimpinnya mara ke hadapan dengan cara mempertingkatkan kecekapan organisasi. Andek Masnah (1999, p. 36) mengungkapkan pemimpin sebagai jaguh, orang terkemuka, pembesar, pengasuh, wali, dan pendidik, manakala memimpin pula bermaksud mengepalai, mengetuai, mempelopori, mendahului dan seumpamanya. Oleh itu, dapat dirumuskan bahawa kepimpinan merujuk keupayaan dan karisma seseorang untuk mengubah hala tuju, kuasa mempengaruhi, menerajui, memantau, mengarah dan menggerakkan sesuatu organisasi untuk mencapai objektif, kejayaan dan matlamat yang digarisi.

Prinsip kepimpinan dalam Pendekatan Pengurusan mengandungi beberapa dimensi. Mohamad Zuber (2017, p. 49) mengklasifikasikan dasar kepimpinan kepada tujuh dasar kepimpinan daripada yang bersifat positif sehinggalah yang memperlihatkan sifat kepimpinan yang negatif. ${ }^{6}$ Walau bagaimanapun, artikel ini mencerakinkan dimensi dalam prinsip kepimpinan kepada empat dimensi sahaja. Ringkasnya, prinsip kepimpinan dalam Pendekatan Pengurusan yang diaplikasikan dalam artikel ini terdapat dalam Rajah 1.

Rajah 1 menunjukkan empat dimensi dalam prinsip kepimpinan, iaitu (i) dimensi pentadbiran, (ii) dimensi pendidikan, (iii) dimensi tanggungjawab sosial dan (iv) dimensi ekonomi. Keempat-empat dimensi ini menjadi landasan analisis terhadap watak wanita dalam novel $W S W$. Dimensi pentadbiran

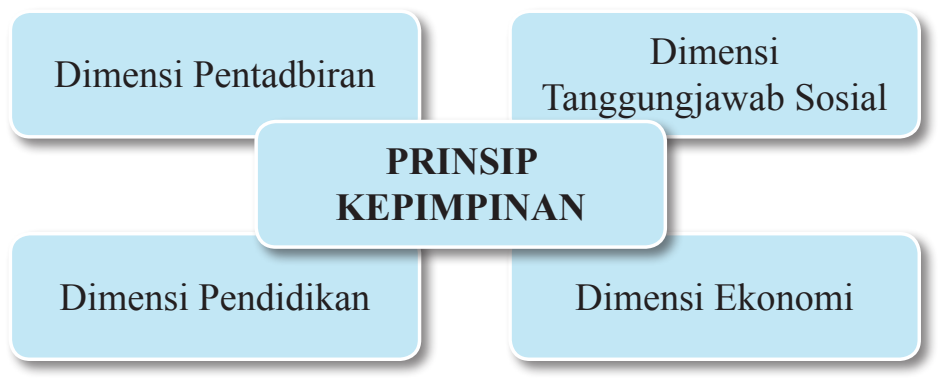

Rajah 1 Dimensi prinsip kepimpinan. 
termasuklah dasar dan gaya kepimpinan yang dipraktiskan pemimpin sama ada lemah, autoritarian, ortodoks, bijak, adil, bersemangat waja, berani, berjiwa rakyat, kejam dan baik hati sehingga mempengaruhi pentadbirannya. Kamus Dewan Edisi Keempat (2019, p. 1564) mentakrifkan pentadbiran sebagai perbuatan mentadbir selain merujuk pengelolaan, pengurusan dan pemerintahan. Pentadbiran pemimpin dalam konteks kajian ini merujuk ketua keluarga mahupun ahli keluarga yang menunjukkan ciri atau bakat kepimpinan menerajui dan mentadbir sesebuah keluarga.

Dimensi pendidikan pula memberikan penekanan terhadap peranan dan tindakan seorang pemimpin dalam sesebuah kerajaan mahupun keluarga untuk mendapatkan sumber ilmu dan usaha bagi memastikan ahli keluarga mahupun anak-anaknya berilmu sama ada secara formal atau tidak formal. Syarifah Alwiah (1993,p. 100) menghuraikan pendidikan sebagai proses atau aktiviti yang melibatkan persekolahan formal. Pendidikan juga sebagai latihan untuk perkembangan fizikal, intelek, sosial dan emosi seseorang individu. Oleh itu, pendidikan formal, tidak formal, pendidikan dunia dan ilmu akhirat sewajarnya diberikan penekanan dalam bidang pendidikan. Mohamad Zuber, Sara dan Mohamad Mokhtar $(2015$, p. 8) berpendapat bahawa pendidikan merupakan salah satu aset yang bermakna dalam membentuk kepimpinan generasi muda sesebuah negara.

Dimensi tanggungjawab sosial pula meneliti aspek tanggungjawab dan sikap yang menunjukkan kebajikan dan kepekaan pemimpin terhadap masalah dan tanggungjawabnya kepada umat yang diperintahnya atau sebuah keluarga yang dinaunginya. Sementara dimensi ekonomi pula merujuk sistem ekonomi yang dipraktiskan pemimpin mahupun ketua keluarga dalam pentadbirannya bagi memakmurkan ekonomi mereka. Mahmud (1988, p. 59) mendefinisikan perniagaan sebagai suatu aktiviti komersial yang diusahakan oleh individu atau kumpulan, perseorangan atau syarikat, yang menjalankan urus niaga jual beli secara besar-besaran. Ringkasnya, dimensi ini memperlihatkan pelibatan usahawan dalam bidang keusahawanan sama ada sebagai perancang, pengurus atau pentadbir ekonomi mahupun sebagai usahawan ke arah yang positif sehingga menyumbang kepada kemakmuran ekonomi negara.

Berdasarkan kaedah analisis dalam Pendekatan Pengurusan, setiap dimensi dalam prinsip kepimpinan ini diteliti berdasarkan tiga bahagian, iaitu apakah dasar, polisi, teknik dan strategi yang dibentuk oleh pemimpin dalam sesebuah pentadbiran? Kedua, bagaimana dasar dan polisi tersebut 
diaplikasi dan diimplementasi oleh pemimpin? Ketiga, sejauh manakah dasar dan polisi tersebut membawa kejayaan dalam sesebuah pentadbiran?

\section{PERBINCANGAN ANALISIS}

Berdasarkan analisis, didapati $W S W$ memaparkan tiga daripada empat dimensi dalam prinsip kepimpinan menerusi kepimpinan wanita pada watak Siti Musalmah. Ketiga-tiga dimensi dalam prinsip kepimpinan yang diperagakan terdapat dalam Rajah 2.

Berdasarkan Rajah 2, didapati WSW memperlihatkan pemotretan kepimpinan wanita dari dimensi pentadbiran, ekonomi dan pendidikan. Dapatan analisis memperlihatkan pengurusan yang signifikan menerusi pemeragaan watak wanita, iaitu Siti Musalmah dalam usaha mengurus, mentadbir dan merancang hala tuju pentadbiran, ekonomi dan pendidikan sebuah keluarga setelah kematian suaminya. Zakaria, Ahmad Munawar dan Noranizah (2012, p. 156) menjelaskan bahawa persekitaran sosial seperti pengaruh ibu bapa, guru, rakan sebaya dan masyarakat menjadi faktor seseorang menjadi pemimpin. Walau bagaimanapun, dalam konteks Siti Musalmah, faktor utama yang menjadi lonjakan terhadap kepimpinannya ialah tanggungjawab dan amanah kepada keluarga setelah kematian suaminya. Siti Musalmah diberikan kekuatan dan kelebihan yang menyamai kekentalan semangat seorang lelaki

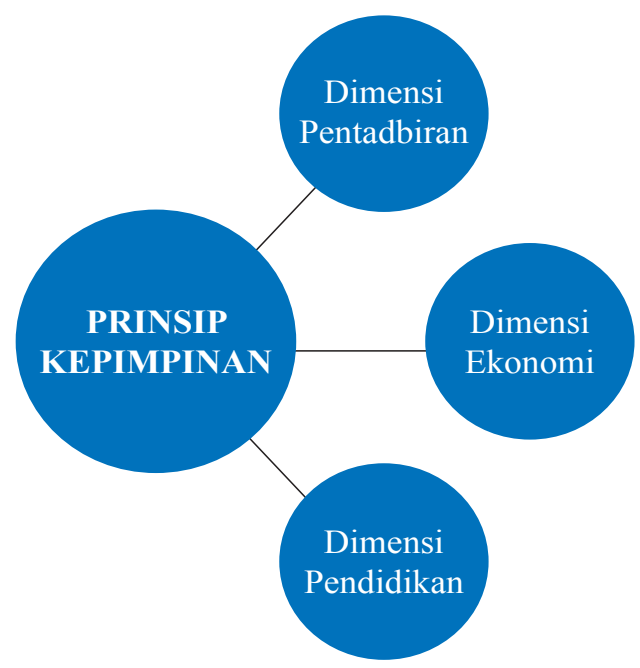

Rajah 2 Potret Kepimpinan Wanita dalam WSW. 
dalam perjuangan untuk menguruskan keluarganya dengan baik. Perkara ini diperkukuh menerusi penemuan Tuan Rusmawati dan Mawar (2018, p.103) bahawa penghasilan watak Siti Musalmah bukan sekadar pelengkap daripada dominasi lelaki, sebaliknya watak ini digambarkan sangat utuh melalui peranan individu, keluarga dan sosialnya. Hakikatnya, watak Siti Musalmah digambarkan tidak tunduk dengan mitos bahawa wanita sangat lemah. Analisis prinsip kepimpinan dalam $W S W$ dibincangkan berdasarkan urutan, iaitu dimensi pentadbiran, dimensi ekonomi dan dimensi pendidikan.

\section{Dimensi Pentadbiran}

Dimensi pentadbiran diperlihatkan menerusi ciri pemimpin yang bertanggungjawab, berwawasan dan dasar pimpinan serikandi. Ketiga-tiga ciri pemimpin pentadbiran ini memperlihatkan pemikiran kepimpinan yang signifikan menerusi watak Siti Musalmah. Tasnim (2018, p.503) berpendapat bahawa wanita dapat memulakan kepimpinan mereka dari rumah dan Islam mengutamakan kepimpinan wanita terhadap anak dengan menunaikan tugasnya sebagai ibu untuk mengasuh dan mendidik dan mempengaruhi anaknya. Dalam WSW, Siti Musalmah dipotretkan sebagai wanita yang bertindak sebagai pemimpin keluarga dengan mendepani pelbagai cabaran demi kelangsungan hidup keluarganya. Ketiga-tiga ciri kepimpinan dalam WSW dipaparkan dalam Rajah 3.

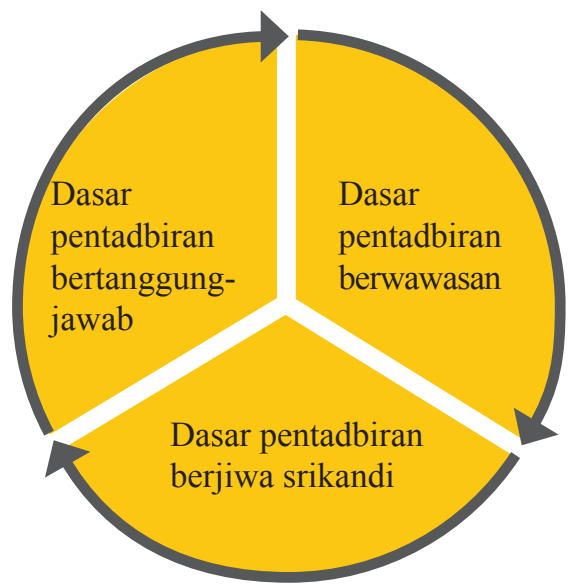

Rajah 3 Potret dimensi pentadbiran wanita dalam WSW. 


\section{Dasar Pentadbiran Bertanggungjawab}

Ciri pemimpin yang bertanggungjawab diperlihatkan menerusi watak yang bertanggungjawab mentadbir keluarganya. Siti Musalmah memikul tanggungjawab keluarga sepenuhnya setelah suaminya Omar, meninggal dunia. Siti Musalmah tidak berkira menjaga ahli keluarganya, malah berikrar bahawa dia akan menjadi ketua rumah dan menanggung keperluan keluarga yang sebelum ini diamanahkan kepada suaminya. Ciri ini diperlihatkan dalam petikan berikut:

Semuanya akan ditanggung dengan rela oleh Siti Musalmah. Dia akan menjadi ketua di dalam rumahnya dan dia juga sekali gus menjadi pentadbir yang bertanggungjawab sepenuhnya ke atas makan minum dan pakaian mereka. Dia harus bekerja keras untuk menyuapkan 10 mulut yang sedang membesar dan sedang menunggu makanan dengan penuh harapan.

(S. Othman Kelantan, 2005, p. 186)

Siti Musalmah bekerja keras menanggung keperluan 10 ahli keluarga yang dahulunya dipikul oleh suaminya, Omar. Oleh itu, Siti Musalmah harus mentadbir urusan keluarganya dengan sebaik-baiknya agar mereka tidak berada dalam kesempitan hidup dan mendapat kesusahan. Seluruh ahli keluarga bergantung harap kepada Siti Musalmah untuk meneruskan kelangsungan hidup setelah suaminya, Omar, yang menjadi tunjang keluarganya meninggalkan mereka buat selama-lamanya.

Sebelum kematian Omar, Siti Musalmah digambarkan sebagai wanita yang bertanggungjawab menjalankan tugasnya sebagai ibu kepada anakanaknya. Sebagai ibu, tanggungjawab membimbing serta menasihati anak-anak terletak di pundaknya. Siti Musalmah menasihati anaknya Siti Fatimah agar menghormati suami apabila mendapati Siti Fatimah kurang mesra dengan suaminya, Muhammad Nur.

"Kau harus banyak bersabar dan berserah kepada Tuhan. Kalau Tuhan telah menjodohkan kita, bermakna itulah takdirnya. Cik tidak suka melihat kau seperti Cik Esyah".

(S. Othman Kelantan, 2005, p. 154)

Petikan tersebut memperlihatkan tanggungjawab yang harus dipikul oleh Siti Musalmah sebagai ibu walaupun anaknya sudah berkahwin. Siti 
Musalmah tidak lepas tangan begitu sahaja apabila melihat situasi Siti Fatimah yang kurang menyukai suaminya. Nasihat Siti Musalmah akhirnya melekat dalam minda Siti Fatimah setelah merenung dan memikirkan nasihat ibunya. "Benar kata-kata ciknya itu. Ibu saudaranya, Siti Aisyah, yang disebutnya Cik Esyah telah menjadi janda" (S. Othman Kelantan, 2005, p.154). Nasihat Siti Musalmah akhirnya meresap dalam jiwa Siti Fatimah dan dia tidak mahu nasibnya sama seperti nasib Siti Aisyah, iaitu ibu saudaranya yang telah menjadi janda. Siti Musalmah mendidik anaknya agar menerima takdir Tuhan yang telah menjodohkannya dengan Muhammad Nur.

Ciri pentadbiran yang bertanggungjawab diimplementasikan oleh Siti Musalmah dengan tekad bekerja keras untuk menanggung keperluan seluruh ahli keluarganya. Dia juga membimbing serta menasihati anak-anaknya agar menerima takdir dan berserah kepada Allah sebagai pencipta setelah berusaha. Berdasarkan ciri ini, Siti Musalmah berupaya dan berjaya menanggung keperluan seluruh ahli keluarganya dengan berniaga dan menasihati anakanaknya agar bergerak mengikut arus kehidupan dengan berpegang pada ketentuan Allah. Kebajikan ahli keluarganya terjamin sehinggalah Siti Musalmah meniti usia emasnya dan menghembuskan nafas yang terakhir. Anak-anak yang dididiknya dapat mengemudikan hidup mereka berlandaskan tanggungjawab dan amanah masing-masing.

\section{Dasar Pentadbiran Berwawasan}

Ciri pimpinan berwawasan ini diperlihatkan menerusi pemikiran watak yang memiliki ciri-ciri berpandangan jauh ke hadapan dalam urusan mentadbir dan mengurus sesebuah keluarga. Seseorang pemimpin mestilah memiliki wawasan, dengan melihat perkara yang tidak dapat dilihat oleh orang lain dan menjangkakan perkara yang tidak dapat dijangka oleh orang lain. Memiliki idea yang menakjubkan untuk mengangkat martabat mereka yang dipimpin. Siti Musalmah dipotretkan memiliki wawasan dengan membuat perancangan lebih awal bagi menghadapi masalah semasa pendudukan Jepun. Sebagai ketua keluarga Siti Musalmah bermuafakat dengan adik-adiknya dan berbincang dengan dua orang anak saudaranya, iaitu Abdullah dan Jaafar secara baik untuk menghadapi masalah pada zaman pendudukan Jepun. Ciri pimpinan ini terdapat dalam petikan berikut:

"Kita mesti bertanam ubi dan jagung," kata Siti Musalmah. 'Tanah di belakang rumah itu boleh digunakan untuk ubi dan jagung. Sekarang 
kita menghadapi musim ka'at. Sebab itu setiap orang mesti bekerja”. Kata-kata itu adalah suatu paksaan yang tidak pernah dilakukan olehnya. Dia berasa seolah-olah memaksa adik-adiknya dan anak-anak saudaranya supaya bekerja untuk makan semasa berada di dalam rumah. Tetapi dia terpaksa mengucapkannya. Barang-barang makanan dan pakaian semakin mahal dan naik harganya.

(S. Othman Kelantan, 2005, p. 259)

Sebelum pendudukan Jepun kehidupan memang selesa tetapi Siti Musalmah tidak mahu keluarganya menghadapi masalah dan kerumitan akibat pendudukan Jepun yang menyekat makanan terutamanya beras. Oleh itu, Siti Musalmah meminta adik-adik dan anak saudaranya bertindak lebih awal sebelum keadaan menjadi rumit dan mereka menghadapi musim $k a$ 'at. Persediaan awal untuk menghadapi zaman yang lebih genting akibat pendudukan Jepun membuktikan Siti Musalmah seorang wanita yang berpandangan jauh ke hadapan dan memiliki wawasan. Pemimpin yang mempunyai wawasan jelas memiliki keupayaan berfikir dengan pelbagai pendekatan bagi mencari alternatif serta mampu memperjelas atau memperhalus sesuatu yang abstrak kepada yang nyata. Pemimpin begini juga memiliki daya kekuatan sehingga mampu menggerakkan orang lain untuk lebih progresif.

Impak atau keberkesanan daripada ciri kepimpinan yang berwawasan menyebabkan keluarga Siti Musalmah terselamat daripada musibah dan penyakit. Setelah tiga tahun pendudukan Jepun di Tanah Melayu, keadaan semakin kronik, ramai yang meninggal dunia kerana kebuluran, pakaian dicatu dan makanan susah didapati. Penyakit pula merebak kerana rakyat kekurangan zat dan ubat. Walau bagaimanapun, keluarga Siti Musalmah tidak sampai ke tahap tersebut, cuma pakaian yang disimpan sudah mula digunakan untuk keperluan dirinya, anak-anak, ibu, adik-adik dan anak-anak saudaranya. Ciri pimpinan berwawasan Siti Musalmah amat berkesan sehingga semua ahli keluarganya hidup sejahtera walaupun pada era pendudukan Jepun yang menindas dan menyusahkan rakyat seperti dalam petikan berikut:

Kalau keadaan berterusan sampai lima enam tahun pun, Siti Musalmah telah mengagak dengan simpanan kain-kainnya, anak-beranaknya masih mampu memakai kain kapas, bukan memakai guni gandum atau guni beras. Bagaimanapun, sebagai persediaan jangka panjang, Siti Musalmah 
mula menyimpan guni gandum yang lembut di dalam sebuah tong kayu di bawah rumah.

Petikan tersebut membuktikan bahawa Siti Musalmah seorang wanita yang berpandangan jauh demi kelangsungan hidup keluarganya. Walaupun keluarganya berada dalam keadaan yang selesa namun Siti Musalmah tetap menyediakan pengurusan risiko untuk masa depan dengan mula menyimpan guni gandum di bawah rumah. Pengurusan risiko amat penting bagi mengelakkan kerugian, kegagalan dan masalah pada masa depan selain membuat persediaan atau perancangan strategik bagi menghadapi musibah. Persediaan ini dibuat bagi memastikan ahli keluarganya tidak bermasalah jika pendudukan Jepun berlarutan. Kepimpinan berwawasan ini sewajarnya dipraktiskan oleh pentadbir sama ada dalam skala yang kecil atau besar demi kelangsungan hidup keluarga mahupun rakyat pada masa depan. Berdasarkan ciri ini, pengarang berjaya memotretkan Siti Musalmah sebagai pentadbir keluarga yang berwawasan.

\section{Dasar Pentadbiran Berjiwa Serikandi}

Wanita biasanya dilabelkan dengan stigma kelembutan dan keayuan. Walau bagaimanapun, watak Siti Musalmah sebaliknya. Siti Musalmah dipaparkan sebagai seorang yang tegas. Dia memimpin keluarganya setelah suaminya meninggal dunia, dan dalam dirinya tersembunyi semangat wirawati. Hal ini diperlihatkan semasa tentera Jepun datang ke rumahnya semasa majlis cukur jambul cucunya kerana menyangka ada perhimpunan di rumah Siti Musalmah. Siti Musalmah dengan jiwa serikandinya telah bersuara lantang dan berani menyatakan bahawa "Tidak ada orang salah di sini tuan." (S. Othman Kelantan, 2005, p. 273) ketika tentera Jepun mengacukan senapang. Semua yang hadir terkesima dan terkejut dengan sikap berani Siti Musalmah yang bersuara nyaring di hadapan tentera Jepun yang memegang senjata api. Siti Musalmah tidak berundur walaupun hujung bayonet itu hampir ke perutnya kerana dalam fikirannya hanya Allah yang menentukan hayat seseorang itu, bukan Jepun. Keadaan ini tidak sedikit pun mematahkan semangatnya untuk terus mempertahankan mereka yang berada dalam majlis cukur jambul cucunya. Situasi tersebut dipaparkan dalam petikan berikut: 
Melihat keadaan itu, seorang askar Jepun lagi melompat naik ke atas tangga dan melangkah ke atas jemuran dengan senapang dan bayonet di hujungnya. Waktu itu, Siti Musalmah berasa dirinya seakan-akan ditembusi peluru atau hujung bayonet yang tajam dan kelihatan putih itu. Tetapi Siti Musalmah tetap degil dan terus menghalang sikap Jepun yang sudah kelihatan marah itu. Jepun itu cuba menerjahkan hujung bayonetnya ke perut Siti Musalmah, tetapi dengan serta merta askar Jepun itu berhenti daripada melakukannya demi mendengar satu suara dari bawah.

(S. Othman Kelantan, 2005, p. 274)

Petikan di atas menunjukkan jiwa serikandi dalam diri Siti Musalmah yang tidak berganjak atau berundur seinci pun walaupun maut menghampirinya. Dia tidak gentar berdepan dengan maut demi keselamatan orang lain yang ada di dalam rumahnya pada waktu itu. Dasar pentadbir berjiwa serikandi yang ditunjukkan oleh Siti Musalmah mencitrakan kekuatan jiwa dan naluri dalaman seorang wanita yang kental dan cekal mengharungi kehidupan. Tindakan Siti Musalmah ini juga berupaya memberikan motivasi kepada golongan wanita yang senasib agar memiliki kekentalan semangat apabila berhadapan dengan cabaran.

\section{Dimensi Ekonomi}

Dimensi ekonomi diperlihatkan menerusi dasar pentadbiran perancang ekonomi dan dasar usahawan wanita dalam mengurus ekonomi. Thuaibah @ Suaibah et al. (2007, p. ii) mendapati bahawa faktor utama yang mendorong usahawan wanita menceburi bidang keusahawanan adalah kerana minat, ingin mencapai cita-cita, serta ingin berdikari. Walau bagaimanapun, penelitian ini memperlihatkan bahawa faktor utama yang mendorong watak Siti Musalmah melibatkan diri dalam perniagaan adalah kerana menggalas tugas ketua keluarga dan desakan ekonomi setelah kematian suami. Desakan ini menyebabkan Siti Musalmah bertindak sebagai perancang dan pengurus ekonomi keluarganya.

Rajah 4 menunjukkan dimensi ekonomi yang dipotretkan menerusi watak Siti Musalmah. Siti Musalmah diberikan kebijaksanaan sebagai perancang atau pengurus ekonomi keluarganya selain memperlihatkan ciriciri usahawan wanita yang berjaya. Berdasarkan dimensi ekonomi, terdapat dua dasar yang diperlihatkan oleh pengarang menerusi watak Siti Musalmah, iaitu dasar perancang ekonomi dan dasar usahawan wanita. 


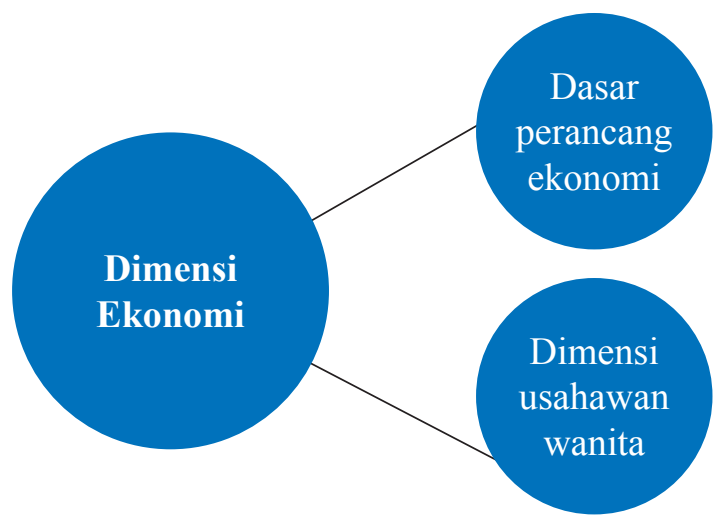

Rajah 4 Potret dimensi ekonomi wanita dalam WSW.

\section{(1) Dasar Perancang Ekonomi}

Siti Musalmah dipotretkan sebagai perancang ekonomi keluarga khususnya setelah suaminya meninggal dunia. Siti Musalmah menyedari hakikat ini setelah kematian suaminya walaupun pada peringkat awal penglibatannya agak perlahan. Tuan Rusmawati dan Mawar (2018, p. 103) berpendapat bahawa watak wanita menerusi perspektif pengarang lelaki tampil dengan pesan kemandirian melalui keupayaan wanita menentukan pilihan sendiri dalam aspek ekonomi. Pendapat ini sejajar dengan tindakan Siti Musalmah yang menentukan sendiri corak ekonomi yang hendak diusahakannya setelah dia memainkan peranan sebagai ketua keluarga. Pada peringkat awalnya, Siti Musalmah meneruskan usaha yang telah ditinggalkan oleh suaminya, termasuklah menguruskan pembelian balak dari Hulu Kelantan.

Perkembangan ekonomi yang pesat di Pangkalan Wakaf Tuk Kasim tidak disia-siakan oleh Siti Musalmah dengan mula membuat perancangan. Pangkalan ini menjadi pusat perniagaan yang beroperasi siang dan malam. Siti Musalmah telah mengambil peluang ini dengan merancang ekonominya sendiri untuk menambah pendapatan keluarga agar tidak hanya bergantung dengan perniagaan kayu balak. Siti Musalmah meneruskan perniagaan dengan memasarkan barangan keperluan rumah tangga di Pangkalan Wakaf Tuk Kasim yang berkembang dengan pesat pada waktu itu, selain memberi tumpuan terhadap perniagaan balak seperti yang dinyatakan: 
Dalam perkembangan itu, Siti Musalmah telah menceburkan dirinya dalam kegiatan ekonomi itu. Dia bukan sahaja menguruskan kilang kayu yang ditinggalkan oleh suaminya, tetapi juga menjalankan kegiatan memasarkan barangan keperluan rumah tangga seperti yang telah dilakukan sebelum kematian suaminya.

(S. Othman Kelantan, 2005, p. 184).

Pendudukan Jepun di Tanah Melayu selama tiga tahun menyebabkan Siti Musalmah jarang ke Pasar Besar di Kota Bharu. Walau bagaimanapun, sebagai perancang ekonomi keluarga, Siti Musalmah tidak berdiam diri walaupun keadaan huru-hara. Siti Musalmah merancang perniagaan keluarganya dengan menjual kuih-muih bersama-sama dengan adik-adiknya. Kuih-muih ini dipasarkan di empat kedai kopi di Pangkalan Wakaf Tuk Kasim bagi menambah pendapatan keluarga. Perancangan Siti Musalmah untuk mengukuhkan ekonomi keluarganya memberikan impak yang positif sepanjang pendudukan Jepun. Perancangan Siti Musalmah menjalankan kegiatan ekonomi dengan berniaga kuih-muih terdapat dalam petikan berikut.

Dia menjalankan kegiatan ekonominya di rumah saja dengan membuat kuih-muih dan dipasarkan di empat kedai kopi di Pangkalan Wakaf Tuk Kasim. Siti Musalmah sendiri membuat ketupat nasi, Siti Aisyah membuat pulut lepa atau pulut panggang berinti serunding ikan atau daging, Siti Khadijah membuat baulu.

(S. Othman Kelantan, 2005, p. 339)

Dalam situasi ekonomi lumpuh akibat pendudukan Jepun, Siti Musalmah bertindak bijak apabila menggunakan mata wang dollar Amerika berbanding dengan mata wang pokok pisang atau Japanese Invasion Money sewaktu menjalankan urusan jual beli. Kebijaksanaan berkaitan erat dengan daya intelektual yang tinggi. Menurut Kamus Dewan Edisi Keempat (2019) intelektual merujuk keupayaan dan kemampuan yang tinggi untuk berfikir seperti keupayaan intelektual Siti Musalmah dalam bertindak menggunakan mata wang yang menguntungkannya. Mata wang Jepun ini dinamakan mata wang pokok pisang oleh penduduk di Tanah Melayu kerana menggunakan simbol tumbuh-tumbuhan yang terdapat di Asia seperti pokok pisang, nenas, buah sukun dan kelapa. Siti Musalmah mengorak langkah dengan menggunakan mata wang dollar yang lebih tinggi nilainya berbanding 
dengan mata wang pokok pisang bagi membolehkannya mendapatkan barang keperluan yang lebih banyak di samping menjimatkan kewangan. Sebagai perancang ekonomi, Siti Musalmah sudah membuktikan kewibawaan dan keintelektualannya dengan mengekalkan penggunaan dollar walaupun wang pokok pisang telah diperkenalkan oleh Jepun.

Ringkasnya, Siti Musalmah telah bertindak sebagai perancang ekonomi keluarga setelah kematian suaminya. Perancangan ekonomi keluarga oleh Siti Musalmah memberikan impak yang positif terhadap pendapatan keluarganya.

\section{(2) Dasar usahawan wanita}

Mohd Asri (1999, p. 23) mendefinisikan usahawan sebagai golongan yang bekerja kuat, mempunyai idea baharu, mempunyai daya cipta dan kreativiti yang tinggi, sanggup menghadapi risiko kehilangan harta benda dan berusaha meningkatkan operasi perniagaan mereka. Definisi tersebut menepati definisi yang diberikan oleh Zaidatol Akmaliah dan Habibah (1997, p. 35), iaitu usahawan merupakan seorang yang memulakan, memiliki dan mengurus perniagaannya sendiri serta sanggup menanggung risiko perniagaan. Selain itu, usahawan juga dikenali sebagai seorang yang inginkan kebebasan dalam perniagaan, membuat keputusan sendiri dan seterusnya ingin berjaya atas usaha sendiri. Pendefinisian ini memenuhi ciri-ciri usahawan wanita yang dimiliki oleh watak Siti Musalmah setelah suaminya meninggal dunia. Siti Musalmah mula melaburkan wang yang diberikan oleh suaminya dengan membeli barang kemas untuk diri dan anak-anaknya. Dia juga membeli barang tembaga dan suasa untuk diniagakan. Siti Musalmah mula bertindak meninggalkan rumah untuk ke Kuala Terengganu berniaga malah sehingga ke Kota Bharu untuk meniagakan barang perhiasan dan barang keperluan rumah tangga seperti periuk, belanga, kuali, tepung, bekas celak dan penyemat baju (S. Othman Kelantan, 2005, pp. 173-174).

Setelah kematian suaminya, Siti Musalmah semakin menggiatkan pelibatannya dalam dunia perniagaan kerana desakan ekonomi dan tanggungjawab mencari rezeki keluarga terletak di pundaknya. Pada peringkat awal pelibatannya dalam perniagaan, dia menjadi pemborong kepada barang-barang peraih di Kuala Besar. Walau bagaimanapun, kebijaksanaan dan bakat yang dimilikinya dalam bidang perniagaan menyebabkan Siti Musalmah menghentikan perniagaannya di Pasar Besar yang memiliki persaingan yang hebat dengan percambahan para peniaga yang menjual hasil tanaman mereka. Siti Musalmah sebaliknya telah berusaha membuka 
kedai sendiri dengan menyewa sebuah kedai di Kota Bharu. Tindakan Siti Musalmah ini bertepatan dengan pendefinisian usahawan oleh Zaidatol Akmaliah dan Habibah (1997) bahawa seorang usahawan berkeinginan untuk membuat keputusan sendiri dan seterusnya ingin berjaya atas usaha sendiri. Siti Musalmah tidak mahu berada di takuk lama dalam perniagaan, sebaliknya mengorak langkah untuk membuka perniagaan sendiri dengan menyewa sebuah kedai.

Setelah usahanya menjadi kenyataan, Siti Musalmah telah memenuhkan gudang yang disewanya dengan barangan kraf tangan daripada perak, tembaga atau suasa, kain batik sarung, kain ela dan barang-barang kemas. Siti Musalmah sanggup ke Pulau Pinang dan Singapura untuk membeli kain yang harganya lebih murah dengan meninggalkan ibu dan anak-anaknya. Dalam usaha membesarkan perniagaannya, Siti Musalmah telah melakukan pengorbanan besar dan bekerja keras. Tindakan Siti Musalmah sebagai usahawan menepati definisi usahawan oleh Mohd Asri (1999) bahawa usahawan sebagai golongan yang bekerja kuat, mempunyai idea-idea baharu dan sanggup mendepani cabaran. Kemanisan dan kejayaan titik peluhnya mula menyerlah setelah bulan ketiga dan keempat berniaga dengan menyewa gudang walaupun pada awalnya agak lembap. Buktinya, "Pada bulan ketiga dan keempat, Siti Musalmah dapat merasakan kelegaannya apabila penjualan kain dan barang-barang kraf tangan dan barang kemas mulai lancar," (S. Othman Kelantan, 2002, p. 359.

Siti Musalmah telah mengukuhkan perniagaannya dengan menubuhkan Syarikat al-Yahya yang menjual pelbagai barangan seperti kain, termasuklah barang yang diimport dari Indonesia. Seorang usahawan yang berjaya akan berusaha meningkatkan operasi perniagaan dengan lebih produktif agar perniagaannya menjadi lebih stabil dan kukuh. Siti Musalmah terkenal dalam kalangan peraih dan penduduk di kawasan Mukim Tebing Tinggi yang meliputi kampung Wakaf Tuk Kasim, Tebing Tinggi, Tasik Gong Nibung, Balik Hulu, Teniat sampai ke Pantai Dasar, Kemeruk, Sabak, Pulau Gajah dan Kemumin hingga ke Pancur (S. Othman Kelantan, 2005, p. 380). Situasi ini memberikan impak yang besar dan signifikan kepada perniagaannya lebih-lebih lagi Siti Musalmah telah menubuhkan syarikat Syarikat al-Yahya yang menjual pelbagai jenis kain, termasuklah yang diimport dari Indonesia. Penubuhan syarikat ini memberikan gambaran kejayaan Siti Musalmah sebagai usahawan wanita.

Kejayaan Siti Musalmah sebagai usahawan wanita telah mendatangkan keuntungan yang lumayan sehingga membawa Siti Musalmah berupaya 
melebarkan sayap perniagaannya. Untuk tujuan itu, Siti Musalmah merancang membeli sebuah rumah niaganya sendiri. Setelah dua tahun menabung wang di bank sebagai persediaan mengembangkan perniagaannya, ruang niaga atau kedainya semakin besar dan berkembang maju. Rentetan dimensi ekonomi seorang usahawan wanita yang berjaya terdapat dalam Rajah 5.

Ringkasnya, Siti Musalmah memperlihatkan kejayaan yang besar sebagai usahawan wanita di Kelantan seperti yang dipotretkan oleh S. Othman Kelantan. Siti Khariah (2012, p.45) menegaskan bahawa jenis perniagaan yang diceburi bergantung pada kemampuan, kebolehan dan minat usahawan yang berkesan. Perkara yang berkaitan dengan penubuhan perniagaan ialah saiz, iaitu bermula daripada saiz kecil yang menggunakan sebuah gerai sementara di pasar minggu sehinggalah kepada saiz yang besar seperti sebuah empayar perniagaan yang mempunyai cawangan di meratarata tempat. Pendapat ini berupaya mencerminkan usahawan wanita seperti

1. Berniaga kecilkecilan menjual barang perhiasan dan barang rumahtangga.

2. Berniaga dan mengurus kilang kayu peninggalan suami.

3. Meluaskan perniagaan di Pasar Besar Kota Bharu.
6. Menyewa gudang untuk berniaga di Kota Bharu.

5. Meneruskan perniagaan di Pasar Besar Kota Bharu selain mengurus kilang kayu.

4. Menjual kuihmuih semasa keadaan huruhara selepas pendudukan Jepun.
7. Menubuhkan syarikat al-Yahya yang menjual pelbagai barang termasuk yang diimport.

8. Membeli ruang niaga sendiri sebagai kedai dan menabung di bank untuk mengembangkan perniagaan.

9. Perniagaan berkembang maju dan terkenal.

Rajah 5 Rumusan dimensi ekonomi. 
Siti Musalmah yang berjaya mengembangkan perniagaannya walaupun bermula secara kecil-kecilan. Dasar usahawan wanita yang diimplementasi Siti Musalmah memperlihatkan keberkesanannya apabila perniagaannya semakin berkembang maju.

Watak Siti Musalmah yang diperagakan S. Othman Kelantan merupakan ikon kepada wanita Kelantan yang aktif dalam bidang keusahawanan. Perkara ini ditegaskan oleh Norshuhaida (2014, p. 5) yang menyatakan bahawa di Malaysia, penglibatan wanita dalam bidang perniagaan sudah lama wujud. Misalnya, di negeri-negeri Pantai Timur Semenanjung seperti Kelantan dan Terengganu, perniagaan di pasar-pasar, pemborong, peruncit dan peniaga di kaki lima banyak dimonopoli oleh kaum wanita. Tambahan pula, peningkatan penyertaan wanita dalam bidang keusahawanan merupakan salah satu daripada agenda utama dalam pemerkasaan ekonomi wanita (Kementerian Kewangan Malaysia, 2013) di Malaysia.

\section{Dimensi Pendidikan}

Dimensi Pendidikan diperlihatkan menerusi ciri pimpinan pendidikan keagamaan dan ciri pimpinan pendidikan berwawasan. Mok (2008, p. 50) merumuskan bahawa pendidikan ialah proses atau aktiviti yang menunjukkan usaha untuk memperkembangkan fizikal, intelek, sosial dan emosi seseorang individu serta menambahkan kemahiran, kebolehan, pengetahuan dan pengalaman supaya dapat memberikan kegembiraan, faedah dan kemajuan dalam kehidupannya. Siti Musalmah memperlihatkan pembudayaan dasar pendidikan mementingkan keagamaan dan pendidikan berwawasan seperti yang dipotretkan dalam Rajah 6.

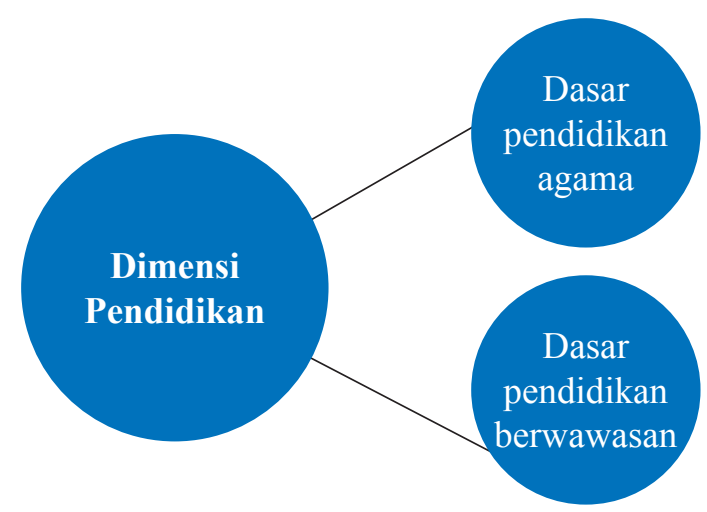

Rajah 6 Potret dimensi pendidikan wanita dalam WSW. 


\section{(1) Dasar Pendidikan Keagamaan}

Siti Musalmah dan suaminya, Omar amat mementingkan pendidikan agama kepada anak-anaknya. Siti Musalmah mengajar anak-anaknya tentang ilmu agama termasuk sahsiah dan peribadi yang mulia. Al-Quran yang merupakan kitab suci agama Islam diajarkan kepada anak-anaknya sebagai kewajipan ibu bapa untuk memenuhi tuntutan agama. Dasar pendidikan yang mementingkan agama menerusi pembacaan al-Quran terdapat dalam petikan berikut:

Yang amat dirasakan bahagia oleh Siti Musalmah ialah anak-anaknya yang tiga orang itu. Muhammad sudah mulai pandai membaca al-Quran daripada surah-surah muqaddam dan mulai pandai sembahyang di belakang abahnya.

(S. Othman Kelantan, 2005, p. 104)

Seperti biasa, setiap pagi Siti Musalmah mengajar anaknya, Husain membaca al-Quran. Sebagai seorang ibu pengasih, Siti Musalmah mengasuh anaknya dengan budi pekerti yang mulia dan bersopan santun. Setelah agak tengah hari sedikit, kira-kira jam 9.00, Husain akan berada di anjung rumah ikut mendengar abahnya membaca kitab.

(S. Othman Kelantan, 2005, p. 135)

Berdasarkan kedua-dua petikan tersebut (p. 104 dan p. 135), didapati Siti Musalmah bukan sahaja bertindak sebagai ibu, malah sebagai guru yang mengajar anak-anaknya mengaji. Semua anaknya diajar membaca al-Quran sejak kecil. Al-Quran merupakan kitab yang diturunkan Allah kepada Nabi Muhammad SAW dan merupakan mukjizat daripada Allah. Membacanya merupakan amal soleh kepada umat Islam. Siti Musalmah sebagai ibu kepada anak-anaknya tidak mengabaikan kewajipan ini dengan memastikan anakanaknya pandai membaca al-Quran sebagai pegangan hidup. Tegasnya, Siti Musalmah sebagai pemimpin dalam keluarganya amat memberikan penekanan terhadap pendidikan keagamaan kepada anak-anaknya agar mereka memiliki ilmu agama yang mencukupi sebagai bekalan dunia akhirat.

Anak-anaknya didedahkan dengan sahsiah dan kehalusan budi pekerti yang mulia agar anak-anaknya menjadi insan yang berguna. Sahsiah dan kehalusan berbudi pekerti yang mulia berhubung rapat dengan konsep sopan atau musoffan. Asmah (2007, p.4) menjelaskan bahawa "sopan merupakan infleksi daripada musoffan dalam bahasa Arab yang disesuaikan dengan 
sebutan Melayu yang membawa makna halus (refined) dari segi tingkah laku". Siti Musalmah mendidik anak-anaknya berlandaskan nilai kesopanan agar mereka membesar sebagai anak yang berpekerti mulia dan memiliki sahsiah serta akhlak terpuji. Tambahan pula akhlak merupakan lambang kesempurnaan iman, ketakwaan dan warisan maknawi yang diwariskan kepada seseorang manusia yang berakal. Dasar pendidikan berlandaskan keagamaan yang diimplementasikan oleh Siti Musalmah memperlihatkan impaknya apabila anak-anaknya berpegang teguh pada ajaran agama dan hidup berlandaskan pegangan dan nilai keislaman. Ghozali dan Kamri (2015, p. 270), menegaskan bahawa akhlak yang baik sebagai salah satu ciri personaliti Islam yang memberikan kesan positif dalam kualiti kerja, manakala Tasnim (2018, p. 503), menegaskan bahawa dalam mencorakkan masa depan anak-anak, wanita harus menghiasinya dengan agama dan amal soleh dan memberikan bimbingan akhlak dan agama yang berkesan.

\section{(2) Dasar Pendidikan Berwawasan}

Seorang pemimpin atau pentadbir dalam keluarga sewajarnya memiliki ciri-ciri pentadbir yang memiliki wawasan dalam pendidikan terhadap ahli keluarganya. Siti Musalmah dipotretkan oleh pengarang sebagai ibu dan pentadbir yang berwawasan dalam usaha mendidik dan menyediakan pendidikan kepada anak-anaknya. Hamka (2017, p.228) menganalogikan bahawa "Rumah adalah kerajaan, isteri ialah Sri Ratu yang mempunyai kuasa yang cukup di dalamnya". Analogi ini mencerminkan pengertian pemikiran yang tersirat tentang besarnya tanggungjawab dan signifikannya peranan seorang wanita dalam rumah tangga untuk mencapai kebahagiaan dan menentukan hala tuju pendidikan anak-anak. Wawasan Siti Musalmah dalam pendidikan anaknya diperjelas seperti dalam petikan:

Bagaimanapun, Ahmad dalam usia tujuh tahun itu sudah menamatkan al-Quran sekali dan mulai berbalik untuk membetulkan bacaan secara mendalam dengan mempelajari nahu. Oleh sebab Siti Musalmah tidak banyak menjalankan kegiatan di luar untuk mencari rezeki, maka sempatlah dia mengajar Ahmad dalam selok-belok hukum-hakam terutama tentang sembahyang dan dan membaca al-Quran. Melihat tubuh Ahmad yang kurus dan kecil, menyebabkan Siti Musalmah tidak memasukkannya ke sekolah. Tetapi apabila memikirkan kecerdasan Ahmad dalam mengikuti pengajian al-Quran dan memahami hukum- 
hakam dalam bab fikah, dia berasa patutlah Ahmad dimasukkan ke mana-mana sekolah atau pondok.

(S. Othman Kelantan, 2005, p. 340)

Siti Musalmah sebagai pentadbir yang berwawasan memperlihatkan kesungguhannya untuk memastikan anak bongsunya, Ahmad mendapat pendidikan agama yang secukupnya. Ahmad merupakan satu-satunya anak lelakinya yang ditakdirkan hidup selepas kedua-dua anak lelakinya, iaitu Muhammad dan Husain dijemput Ilahi semasa kecil. Dalam usia tujuh tahun, Ahmad sudah tamat membaca al-Quran dan dalam proses mendalami kitab tersebut. Ahmad dalam usia yang sangat muda itu juga sudah memahami hukum-hakam fikah dan mengikuti pengajaran kitab Musalli ayah saudaranya. Dalam usia begitu, pencapaian ini merupakan kejayaan besar kepada Siti Musalmah dan Ahmad sendiri. Tindakan Siti Musalmah untuk memasukkan Ahmad ke sekolah pondok memanifestasikan wawasannya. Pimpinan yang berwawasan dalam usaha mencorakkan masa depan anaknya, Ahmad, turut terbukti dalam petikan berikut:

Dia seharusnya memasukkan Ahmad ke pondok di Kota Bharu sama ada pondok Bunut Payung atau Pondok Kampung Sirih. Tetapi dia juga memikirkan tuntutan dunia baru memerlukan sedikit perubahan kepada corak pendidikan anak lelakinya. Tambahan pula sekolah Sabak itu berdepan saja dengan Pangkalan Wakaf Tun Kasim. Cik pun tahu pesan abah Mad itu. Tetapi ini tidak apa kalau masuk sekolah Melayu. Di sekolah itu pun ada bahagian agamanya. Kalau Mad masuk sekolah Melayu, Mad dapat dua jenis pelajaran. Satu pelajaran Melayu yang mustahak sekarang ini dan dapat juga ilmu agama kerana di sekolah pun ada diajar agama".

(S. Othman Kelantan, 2005, p. 354)

Dasar pimpinan pendidikan yang berwawasan menyerlah apabila Siti Musalmah sudah memikirkan untuk menghantar Ahmad ke sekolah pondok ataupun ke sekolah Melayu. Situasi semasa pada zaman tersebut memperlihatkan kecenderungan ibu bapa menghantar anak-anak mereka ke sekolah pondok. Walau bagaimanapun, Siti Musalmah sudah berpandangan jauh untuk pendidikan anaknya, Ahmad. Siti Musalmah sudah memikirkan kepentingan belajar di sekolah Melayu agar Ahmad mendapat ilmu yang holistik. Siti Musalmah mahu Ahmad belajar di sekolah Melayu kerana di 
sekolah itu Ahmad akan belajar dua jenis pelajaran, iaitu pelajaran Melayu yang amat mustahak pada masa itu (pelbagai mata pelajaran) dan ilmu agama kerana di sekolah Melayu juga diajar tentang agama. Wawasan ini membolehkan Ahmad menjadi guru suatu hari nanti, tidak hanya mengajar di sekolah pondok seperti tukku (datuk) dan ayahnya. Pemikiran Siti Musalmah menandakan wawasannya untuk memberikan pendidikan yang terbaik untuk anaknya, agar Ahmad dapat memperoleh ilmu yang luas dan holistik selain berupaya menempatkan dirinya di mana-mana sekolah, tidak hanya di sekolah pondok. Wawasan Siti Musalmah menjadi kenyataan apabila Ahmad telah berjaya menjadi guru. Buktinya menerusi petikan, iaitu "Siti Musalmah berasa amat bertuah kerana anaknya Ahmad memang benarlah seperti yang dicita-citakan oleh anaknya itu, telah menjadi guru" (S. Othman Kelantan, 2005, p. 388). Ahmad telah mengajar di Geting, Berangan dan kemudiannya di Kampung Gunung. Ilmu pengetahuan yang dimiliki Ahmad bersifat menyeluruh hasil daripada dasar pendidikan berwawasan Siti Musalmah pada peringkat awal persekolahan Ahmad.

Dasar yang dipraktiskan oleh Siti Musalmah ini bertepatan dengan penegasan Wan Abdul Kadir (2000, p. 13) yang memperkatakan bahawa nilai dalam kehidupan orang Melayu bersandarkan al-Quran dan hadis yang diperlihatkan menerusi perbilangan adat yang berbunyi: "Adat bersendi hukum, hukum bersendi kitab Allah". Penekanan pengarang terhadap nilai keagamaan didapati sinonim dengan dapatan Mohamad Zuber, Sara dan Mohamad Mokhtar (2014) dalam teks prosa tradisional cerita lipur lara.

\section{KESIMPULAN}

Berdasarkan perbincangan, ternyata novel WSW berupaya untuk memotretkan dasar kepimpinan oleh seorang ketua keluarga berdasarkan acuan Pendekatan Pengurusan. Watak Siti Musalmah dideskripsikan oleh pengarang sebagai wanita yang berkarisma, berkaliber, bijaksana, kental dan kuat keimanannya sehingga berjaya menjadi peneraju keluarga setelah kematian suaminya. Kejayaan Siti Musalmah yang lebih ketara diperlihatkan menerusi tindakannya mengurus keluarganya kerana ciri-ciri kepimpinan yang ada padanya, iaitu melalui dasar pentadbiran, dasar ekonomi dan dasar pendidikan.

Pembudayaan dasar pentadbiran bertanggungjawab memanifestasikan prinsip hidup wanita yang berusaha untuk memastikan ahli keluarganya hidup sejahtera. Siti Musalmah turut mempraktiskan pentadbiran yang berwawasan bagi mengurus ekonomi keluarganya. Pentadbir yang berwawasan dapat 
menentukan kejayaan sesebuah organisasi atau keluarga kerana pemimpin begini akan mengambil langkah yang sistematik, konstruktif dan kompetitif bagi menjamin kelangsungan sesebuah keluarga. Dasar pentadbiran serikandi yang dipraktikkan oleh Siti Musalmah memperlihatkan kekuatan dalamannya untuk menjamin keselamatan keluarga. Sehubungan dengan itu, pengurusan ekonomi yang diimplementasi oleh Siti Musalmah menunjukkan kejayaannya sebagai perancang ekonomi keluarga selain sebagai usahawan wanita yang berjaya mengembangkan perniagaannya.

Siti Musalmah juga dipotretkan sebagai ketua keluarga yang berjaya mengurus pendidikan dengan mempraktiskan dasar pendidikan yang mementingkan keagamaan, iaitu bersandarkan al-Quran. Nilai-nilai keislaman, iaitu pendidikan dalam aspek keagamaan yang meliputi pengajian al-Quran, ilmu nahu dan mantik, yang menjadi aspirasi pemikiran pengarang yang berjaya mengangkat dan memaparkan aspek pengurusan menerusi dimensi pendidikan. Tuntasnya, pengaplikasian Pendekatan Pengurusan menerusi prinsip kepimpinan berupaya membuktikan novel WSW mengandungi aspek pengurusan dari segi kepimpinan dalam keluarga.

\section{NOTA}

1 "Terpasung" dalam bahasa Indonesia bermaksud terbelenggu, terkongkong, terhalang yang merujuk situasi kaum wanita yang tidak bebas untuk bertindak dan melibatkan diri dalam pelbagai bidang.

2 Perbincangan dalam kertas kerja ini memfokuskan prinsip perancangan, iaitu salah satu prinsip dalam Pendekatan Pengurusan. Berdasarkan kajian ini, didapati di sebalik nilai moral dan didaktik yang terpancar dalam cerita rakyat unsur pengurusan, iaitu aspek perancangan yang dikesan dalam cerita "Sang Kancil dengan Buaya".

3 Kajian ini menggunakan prinsip kepimpinan berdasarkan dimensi pendidikan berdasarkan cerita lipur lara. Dapatan menunjukkan tradisi keilmuan dalam Hikayat Awang Sulung Merah Muda diperlihatkan menerusi pendidikan tidak formal berkaitan dengan nilai keislaman dan pentingnya pendidikan dalam aspek keagamaan yang meliputi pengajian al-Quran, ilmu nahu dan mantik, ilmu persilatan dan kepahlawanan Melayu serta amalan mulia yang perlu dipraktiskan dalam kehidupan seharian.

4 Kajian ini menggunakan prinsip perancangan dalam Pendekatan pengurusan. Dapatan menunjukkan pembentukan strategi penyelesaian masalah yang bervariasi oleh watak Bayan bagi mengatasi masalah atau isu moral berhubung dengan pelanggaran moral dan etika oleh watak Bibi Zainab. Pembentukan strategi penyelesaian masalah yang bervariasi ini memperlihatkan bahawa perancangan bestari dan sistematik amat signifikan.

5 Makalah ini menggunakan prinsip kepimpinan untuk menganalisis data prosa tradisional yang bertajuk "Kepimpinan melalui Teladan" dalam Antologi Jaket Kulit dari Istanbul. Dapatan menunjukkan bahawa pemimpin Melayu Melaka mempraktiskan 
dimensi pentadbiran dan dimensi tanggungjawab sosial dalam prinsip kepimpinan bagi memastikan kestabilan dan kegemilangan kerajaan yang diperintahnya. Dimensi pentadbiran diperlihatkan menerusi dasar kepimpinan yang bijaksana, kepimpinan yang adil, kepimpinan berjiwa rakyat, kepimpinan yang bersemangat waja dan kepimpinan yang baik hati atau pemurah..

6 Mohamad Zuber (2017, p.49) mengklasifikasikan dasar kepimpinan kepada tujuh dasar, iaitu (i) Dasar kepimpinan berani/bersemangat waja/kepahlawanan, (ii) Dasar kepimpinan bijaksana/berwawasan/ berpandangan jauh, (iii) Dasar kepimpinan amanah/jujur/menepati janji, (iv) Dasar kepimpinan bertanggungjawab/adil, (v) Dasar kepimpinan bertimbang rasa/penyayang/berjiwa rakyat, (vi). Dasar kepimpinan mementingkan pendidikan dan (vii) Dasar kepimpinan penipu/memfitnah.

\section{RUJUKAN}

Adawiyah Ismail \& Salasiah Hanin Hamjah. (2012). Kefahaman Terhadap Kedudukan Wanita Bekerjaya menurut Islam. Jurnal al-Hikmah, Bil. 4, 3-14.

Andek Masnah Andek Kelawa. (1999). Kepimpinan wanita dalam Islam. Bangi: Penerbit Universiti Kebangsaan Malaysia.

Annisa Fitriani. (2015). Gaya Kepimpinan Perempuan. Jurnal Teropong Aspirasi Politik Islam TAPIs, 11(2), 1-24.

Asmah Omar. (2007). Kesantunan Bahasa dalam Pengurusan Pentadbiran dan Media. Kuala Lumpur: Dewan Bahasa dan Pustaka.

Azman Mat Hassan. (2012). Persepsi Gaya Kepimpinan terhadap Kepuasan Kerja. Jurnal Penyelidikan Islam, 25, 121-136.

A. Samad Said. (1985). Daerah Zeni. Kuala Lumpur: Dewan Bahasa dan Pustaka. Cartwright. D \& Zander A. (1960). Group Dynamics Research and Theory. Evanston: Row Peterson And Co.

Ghozali, M \& Kamri, N. A. (2015). Keperibadian Islam dan Profesionalisme dalam Pekerjaan: Satu Analisis Teoritis. Jurnal Syariah, 23(2), 255-286.

Hamka. (2017). Lembaga Hidup. Batu Caves, Selangor: PTS.

Kamus Dewan Edisi Keempat. (2019). Kuala Lumpur: Dewan Bahasa dan Pustaka. Kementerian Kewangan Malaysia. (2013). Laporan ekonomi 2013/2014. Kuala Lumpur: Malaysia.

Mahmud Muhammad Babilli. (1988). Ekonomi dari Kaca Mata Islam. Kuala Terengganu: Syarikat Pencetakan Yayasan Islam Terangganu Sdn. Bhd.

Mohamad Asri Abdullah. (1999). Pembangunan Industri Kecil dan Sederhana. Kuala Lumpur: Utusan Publications \& Distributors Sdn. Bhd.

Mohamad Mokhtar Abu Hassan. (2013). Pendekatan Pengurusan: Satu Metode dalam Kritikan Sastera. Kertas kerja yang dibentangkan dalam Himpunan Ilmuwan Sastera Melayu Malaysia Kedua, Universiti Perguruan Sultan Idris, 4-5 Oktober. 
Mohamad Mokhtar Abu Hassan. (2016). Pendekatan Pengurusan dalam Kritikan Kesusasteraan. Akademi Pengajian Melayu: Universiti Malaya Kuala Lumpur.

Mohamad Zuber Ismail, Sara Beden \& Mohamad Mokhtar Abu Hassan (2014). Hikayat Awang Sulung Merah Muda dari Perspektif Pendekatan Pengurusan. Jurnal Pengajian Melayu, 26, 95-116.

Mohamad Zuber Ismail, Sara Beden \& Mohamad Mokhtar Abu Hassan. (2015). Keintelektualan Pemikiran Melayu dalam Cerita Lipur Lara. The Journal of Business and Social Development, 3(2), (1-16).

Mohamad Zuber Ismail. (2017). Kajian Cerita Lipur Lara Terpilih Berdasarkan Pendekatan Pengurusan (Tesis Kedoktoran yang tidak diterbitkan). Kuala Lumpur: Akademi Pengajian Melayu, Universiti Malaya.

Mok Soon Sang. (2008). Psikologi Pendidikan dan Pedagogi: Murid dan Alam Belajar. Puchong, Selangor: Penerbitan Multimedia Sdn. Bhd.

Muhammad Rahimi Hasan \& Bahiyah Abdul Hamid. (2017). Pembangunan Kepimpinan Wanita: Membina Ilmu Watan bagi Kepimpinan Wanita Menerusi Kehidupan Tun Fatimah Hashim. Kajian Malaysia, 35(1), 91-116.

Nik Safiah Karim. 1990. Wanita Malaysia: Harapan dan Cabaran. Kuala Lumpur: K Publishing \& Distributors.

Northouse, P. G. (2007). Leadership: Theory and Practice. California: Sage.

Nor Aziza Abdul Aziz, Kamar Musa \& Haniza Kandar. (2018). Faktor yang Mempengaruhi Kejayaan Usahawan Wanita. e-Proceedings National Innovation and Invention Competition Through Exhibition.

Norshuhaida Mohamad. (2014). Faktor-Faktor Kejayaan dan Masalah dalam Pengendalian Perniagaan di Kalangan Usahawan Wanita di Dua Buah Daerah di Negeri Kelantan (Tesis Sarjana tidak diterbitkan). Tanjung Malim: Universiti Pendidikan Sultan Idris.

Rosnani Md Zain \& Nik Rafidah Nik Muhamad Affendi. (2018). Karisma Wanita dalam Novel Nenek Karya Razali Endun. Jurnal Sultan Alauddin Sulaiman Shah, 5(1), 44-54.

Sara Beden. (2018). Perancangan Bestari dalam "Hikayat Khoja Maimun”: Aplikasi Prinsip Perancangan dalam Pendekatan Pengurusan. Malay Literature, 31(1), 69-97.

Sara Beden. (2019). Analisis Prosa Klasik “Kepimpinan Melalui Teladan” Berdasarkan Prinsip Kepimpinan. Malay Literature. 32(1), 37-70.

S. Othman Kelantan. (2005). Wajah Seorang Wanita. Kuala Lumpur: Dewan Bahasa dan Pustaka.

Siti Khariah M. Zubir. (2012). Analisis Citra Usahawan Wanita dalam Novel-Novel Melayu. Jurnal Perspektif, 4(2), 44-55.

Shaharom Husain. (1991). Drama-drama Shaharom Husain. Kuala Lumpur : Dewan Bahasa dan Pustaka.

Syarifah Alwiah Alsagoff. (1993). Ilmu Pendidikan Pedagogi. Kuala Lumpur: Heinemann Asia. 
Shellabear, W.G. (1989). Sejarah Melayu. Petaling Jaya: Fajar Bakti.

T. A. Ridwan. (2001). Bahasa Melayu: Peranan dan Nilai-nilai Moralisme di Dalamnya. Kosmologi Melayu. Kuala Lumpur: Akademi Pengajian Melayu. Tasnim Abdul Rahman. (2018). Kepimpinan Wanita dari Kacamata Islam. Prosiding Seminar Antarabangsa al-Quran dalam Masyarakat Kontemporari. Anjuran Fakulti Pengajian Kontemporari Islam (FKI), Universiti Sultan Zainal Abidin (UniSZA), p.502-616.

Tenas Effendy. (2010). Kearifan pemikiran Melayu. Pekanbaru: Yayasan Tenas Effendi. Thuaibah@Suaibah Abu Bakar, Azlah Md Ali, Rozeyta Omar, Hishamuddin Md Som \& Syaharizatul Noorizwan Muktar. (2007). Penglibatan Kaum Wanita dalam Aktiviti Keusahawanan di Negeri Johor: Kajian Terhadap Faktor-Faktor Kritikal Kejayaan dan Kegagalan Pengendalian Perniagaan. Laporan Akhir Penyelidikan. Universiti Teknologi Malaysia: Jabatan Pembangunan Sumber Manusia Fakulti Pengurusan dan Pembangunan Sumber Manusia.

Tuan Rusmawati Raja Hassan \& Mawar Safei (2018). Kemandirian Wanita dan Ekonomi Kelantan: Satu Analisis Autobiografi terhadap Novel Wajah Seorang Wanita. Geografia Malaysian Journal of Society and Space, 14(4), 102-114.

Tuan Rusmawati Raja Hassan, Mawar Safei \& Muammar Ghaddafi Hanafiah (2018). Jurnal Melayu, 17(2), 178-196.

Wan Abdul Kadir. (1998). Tradisi Budaya Melayu Berteraskan Islam. Jurnal Pengajian Melayu, 8, 82-97.

Zaidatol Akmaliah Lope Pihie \& Habibah Elias. (1997). Keusahawanan dan Motivasi Diri. Serdang: Penerbit Universiti Putra Malaysia.

Zakaria Stapa, Ahmad Munawar Ismail \& Noranizah Yusuf. (2012). Faktor Persekitaran Sosial dan Hubungannya dengan Pembentukan Jati Diri. Jurnal Hadhari, Special Edition, 155-172.

Received: 15 June 2020

Accepted: 24 November 2020 